Article

\title{
Negotiations of Socio-Spatial Coexistence through Everyday Encounters in Central Athens, Greece
}

\author{
Eva (Evangelia) Papatzani ${ }^{1, *}$ and Lena Knappers ${ }^{2}$ \\ ${ }^{1}$ Department of Urban and Regional Planning, School of Architecture, National Technical University of Athens, \\ 10682 Athens, Greece; E-Mail: epapatzan@central.ntua.gr \\ 2 Independent Researcher, 3012 Rotterdam, The Netherlands; E-Mail: lenaknappers@gmail.com \\ * Corresponding author
}

Submitted: 9 February 2020 | Accepted: 15 May 2020 | Published: 28 July 2020

\begin{abstract}
Over the past decades, Athens has emerged as both a destination and gateway city for diverse migrant populations. Athenian urban development interrelated with migrants' settlement dynamics has resulted in a super-diverse and mixed urban environment. This article focuses on the western part of Omonia, in central Athens, Greece, and investigates sociospatial trajectories of migrants' habitation, entrepreneurship, and appropriation of (semi-)public spaces. It draws on scholarship about everyday encounters where negotiations of difference and interethnic coexistence take place at the very local level. It explores encounters between migrants, as well as between migrants and locals, that are created due to their everyday survival and social needs. The article argues that these 'place-specific' and 'needs-specific' encounters emerge as 'micropublics' that are open to negotiation, manage to disrupt pre-existing social boundaries, and epitomise processes of belonging in the city. The article draws from ethnographic fieldwork and qualitative semi-structured interviews carried out from 2013 to 2014 and from 2018 to 2019.
\end{abstract}

\section{Keywords}

Athens; everyday encounters; local diversity; micropublics; migrants' settlement; socio-spatial coexistence; urban space

Issue

This article is part of the issue "Urban Arrival Spaces: Social Co-Existence in Times of Changing Mobilities and Local Diversity" edited by Yvonne Franz (University of Vienna, Austria) and Heike Hanhörster (ILS-Research Institute for Regional and Urban Development, Germany).

(C) 2020 by the authors; licensee Cogitatio (Lisbon, Portugal). This article is licensed under a Creative Commons Attribution 4.0 International License (CC BY).

\section{Introduction}

In an era of never-ending forced mobility, migration is constantly reshaping the world, cities, and the local level. Urban space has been diachronically interrelated with the dynamics of migrants' settlement and movement, as on the one hand, urban and economic development affect the (re)production of migratory flows and on the other, migrant populations transform urban spaces in which they settle by influencing everyday life processes. Relevant scholarship from the Chicago School of Sociology, which emerged almost a century ago, has been widely spread but is at the same time extensively criticised for its deterministic approach on migrants' trajectories (Park, Burgess, \& McKenzie, 1925). Over decades, urban scholars analysed the rising socio-spatial complexity of urban environments and migrants' settlement patterns (Arapoglou, 2006; Leontidou, 1990; Soja, 2000). Furthermore, scholarship on the relationships between migration and the city has been inspired by the critical urban theory and determined by Lefebvre's analysis of space as a social product (Lefebvre, 1974), Soja's socio-spatial dialectic (Soja, 1989) and Massey's notion of space as a "simultaneity of stories-so-far" (Massey, 2005, p. 9)

Urban space is where the possibility of contact and encounter between 'strangers' emerges and where "living with difference" (Valentine, 2008) is primarily nego- 
tiated. As Young notes, "city life is a being together of strangers, diverse and overlapping neighbors" (Young, 1990, p. 240). 'Strangers' are characterised by both spatial proximity and social distance (Wolff, 1950), while their recognition is taking place through encountering them in space (Horgan, 2012). The relationships between strangers, or 'strangership,' as Horgan (2012) has argued, constitute spatial processes of physical approximation and encounter. In the words of Massey, place "as an evershifting constellation of trajectories" poses the question of living together, which is "the central question of the political” (Massey, 2005, p. 151).

Many cities worldwide are constantly transforming due to migrants' movement and settlement. Over the past decades, Athens has emerged as both a destination city and a gateway for migrants on their journey to Europe. After the dissolution of the Soviet Union, migrant flows from Eastern Europe and the Balkans transformed Greece into a destination country. Since the late-2000s, the Greek-Turkish borders have become the main European entry points for migrants from the Middle East, Africa, and Asia. More recently, during the so-called 'refugee crisis' of 2015 , more than a million asylum seekers and refugees from Syria, Afghanistan, Iraq, and other countries arrived in Greece, strengthening its transit character. After the closure of the Western Balkan Route in 2016, significant numbers of asylum seekers were trapped in the country for indefinite periods of time.

Athenian urban development interrelated with migrants' settlement dynamics has resulted in a superdiverse and mixed urban environment where different migrant groups and locals reside in spatial proximity. This article focuses on the western part of Omonia in central Athens (known as 'Gerani') and investigates socio-spatial trajectories of migrants' habitation, entrepreneurship, and appropriation of (semi-)public spaces. Omonia has multiple functions for the everyday life of migrants in the city-it is a place of long-term residence, a pole of attraction for diverse ethnic groups and locals, and an arrival space for newcomers. The article draws on scholarship about everyday encounters where negotiations of difference and interethnic coexistence unfold at the very local level. It explores encounters between migrants, as well as between migrants and locals that are created due to their everyday survival and social needs. The article argues that these 'place-specific' and 'needsspecific' encounters emerge as 'micropublics' that are constantly open to negotiation and manage to disrupt both pre-existing social identities and boundaries and local power relations. Besides, through these micropublics, processes of not only negotiating socio-spatial coexistence but also belonging in the city are epitomised.

The research presented in this article combines both quantitative and qualitative methods. Quantitative data on the migrant population and ethnic businesses in the area are provided by the Panorama of Greek Census Data (EKKE-ELSTAT, 2015) and the Athens Chamber of Commerce and Industry. The core of the research was implemented through qualitative and ethnographic methods. In situ observation, mapping, informal discussions (15), walking interviews (tours guided by migrant interviewees; 3) and in-depth semi-structured interviews (21) were conducted during two different periods, from 2013 to 2014 and from 2018 to 2019 for the needs of two different research projects. The semistructured interviews were conducted with migrants who arrived in the late-2000s from Middle Eastern, Asian and African countries (9), refugees (5) who had arrived since 2015 and Greeks (7), either residing, working, or visiting Omonia during their leisure time, both men (16) and women (5). The immigrant interviewees were both documented (4) and undocumented (5), a choice based on the crucial role of the latter in everyday urban dynamics (Varsanyi, 2008), while refugee interviewees were mostly assigned asylum seekers and not recognised beneficiaries of international protection. The names of the interviewees presented in the article have been changed for confidentiality-related reasons. The methodology draws from an agenda for urban research that simultaneously examines the diversity of subjects, practices, and places (van Kempen \& Wissink, 2014). Rather than focusing solely on one ethnic group, or one sector of activity (e.g., housing or ethnic entrepreneurship), the article explores a specific urban environment, as the dynamics of sociospatial coexistence can be understood only through the investigation of contextual spatialities (Glick Schiller \& Çağlar, 2009; Vaiou et al., 2007).

\section{Local Diversity, Spaces of Encounters and Socio-Spatial Coexistence: Theoretical Considerations}

Emerging in the wave of academic and political criticism on multiculturalism, 'diversity' stands for the rising complexity of contemporary migration in cities. The notion of 'super-diversity,' as introduced by Vertovec, refers to "new conjunctions and interactions of variables" (Vertovec, 2007, p. 1025) and aims to capture the multiple characteristics of social groups, such as gender, age, language, legal status, labour market experiences and patterns of spatial distribution (Vertovec, 2007). Thus, super-diversity aims to go beyond 'traditional' approaches that focused mainly on the investigation of ethnicity or specific groups. For many scholars, super-diversity is a helpful concept as it both focuses on the increasing complexity of the dimensions of difference and is locally grounded, permitting "to be alert to the spatial dimensions of the politics of difference" (Berg \& Sigona, 2013, p. 348). The notion of 'hyper-diversity' has been also introduced, referring to "an intense diversification of the population in socio-economic, social and ethnic terms, but also concerning lifestyles, attitudes and activities" (Tasan-Kok, van Kempen, Raco, \& Bolt, 2013, p. 6). A body of critical approaches to super-diversity has emerged recently, arguing against the romanticised perceptions accompanying the term. Super-diversity as 
an analytical framework conceals crucial structures of power, oppression, and exclusion because it downplays the role of 'old' categories of difference such as race, class, and gender (Aptekar, 2019). Other contributions have drawn from the experience of southern European cities, and focused on the relationships between diversity and socio-economic inequality by highlighting that super-diversity may exist in parallel with the reproduction of social fragmentation and exclusion, even without the spatial segregation of social groups (Arapoglou, Kandylis, Kavoulakos, \& Maloutas, 2009).

Diversity has also been approached as a lived experience through the investigation of everyday encounters with difference (Valentine, 2008) in urban space. Everyday encounters constitute an issue that has gained significant attention in philosophical, sociological and urban studies. From Goffman's (1961) studies on encounters through the lens of the sociology of interaction, or Althusser's "underground current of the materialism of the encounter" (Althusser, 2006), encounters with the 'stranger' emerge as processes of contact that reflect a micro-picture of the worlds' complex social relationships. Closely related with the notion of contact, scholarship on encounters with difference has been inspired by the 'contact hypothesis' (Allport, 1954), according to which increased contact is capable of reducing prejudice and mediating difference. A significant part of urban studies has focused on processes of social approximation produced through everyday interactions in super-diverse contexts, highlighting their role in strengthening local interethnic coexistence (Hall, 2015; Wessendorf, 2010). As such, encounters emerge also as spatial processes, as 'strangership' involves encounter and approximation as some of the necessary conditions to unfold (Horgan, 2012). At the same time, space is also "constituted by the dialogical encounter of groups" (Isin, 2007, p. 223).

Nevertheless, following the criticism on superdiversity, the idea of contact and encounters as processes generating only positive social proximity and respect for 'the Other' has been intensively questioned (Matejskova \& Leitner, 2011; Valentine, 2008). Instead, encounters may also involve conflict (Ahmed, 2000). Fleeting encounters do not equate with 'meaningful contact' (Valentine, 2008) and spatial proximity through encounters in public spaces is not always capable of creating social proximity (Matejskova \& Leitner, 2011). Also, it has been argued that encounters can both bring 'strangership' into being and highlight inequality (Horgan, 2012). The major factors affecting everyday encounters with difference, which are usually left out of the analysis, are inequalities, systemic oppressions, and exclusions, as well as the particular historical and geographical contexts of unequal power relations between social groups (Aptekar, 2019; Matejskova \& Leitner, 2011; Nast \& Blokland, 2014).

By understanding the 'accomplishment of difference' as a dynamic process (Aptekar, 2019), the lens, through which encounters are investigated, should be spatialised and contextualised. The specific socio-spatial context, in which encounters take place, is of crucial importance for their impact on everyday interactions. Amin (2002) argues that encounters in public spaces may not provide the possibility of sustained interactions, and suggests shedding light on other semi-public spaces, as 'micropublics' or "micropolitics of everyday social contact and encounter" (Amin, 2002, p. 959) taking place in the microscale of "everyday lived experiences and local negotiations of differences" (Amin, 2002, p. 967). Matejskova and Leitner (2011) argue that encountering otherness in specific places, such as their case study on neighbourhood community centres, could foster sustained and close relationships. Nast and Blokland (2014) urge to focus on a context-specific investigation of networks and neighbourhoods' institutional settings in particular rather than on residential neighbourhoods in general (Nast \& Blokland, 2014). Mayblin, Valentine, and Andersson (2016) analyse the concept of 'contact zones' as spaces of purposeful organised activities that engineer meaningful contact. Wessendorf (2014) draws on the differentiation between the public, parochial and private realm and conceptualises the 'parochial spaces' as semi-public spaces characterised by closer relationships among neighbours. Realms are not always related to specific physical spaces, the boundaries between them are fluid, and spaces considered private or public could function in specific situations as parochial (Wessendorf, 2014).

Thus, the specific characteristics of the spatial context, in which-and the practices or activities through which-everyday encounters are taking place, come to the forefront. Semi-public, or 'in-between' spaces, compared to public ones, emerge as capable of providing stronger potentials for the positive negotiation of living with difference, especially when they are related to specific activities, practices, and needs. Such 'spaces of encounters' (Leitner, 2012), Fraser's (1992) 'counterpublics' and Amin's (2002) 'micropublics' constitute what we might describe as 'place-specific' encounters that until today remain open for the contemporary negotiation of difference and interethnic coexistence. These encounters are considered as dynamically open, able to disrupt preconceived boundaries and racial stereotypes (Leitner, 2012), to involve both current subjects and past histories (Ahmed, 2000) and to enact a politics of belonging. It is at this particular point that the present article aims to contribute: by investigating 'place-specific' and 'needs-specific' encounters, as 'micropublics' (following Amin's term) fostering social proximity and coexistence, emerging in everyday spaces where survival and social needs are covered through specific activities and practices. Following the criticism of Glick Schiller and Çağlar (2009) on the 'ethnic lens' usually adopted in migration urban research and despite the extended scholarship on diversity and interethnic coexistence, fewer studies have examined super-diverse and mixed contexts where no ethnic group constitutes a dominant major- 
ity. Additionally, less attention has been paid to urban contexts where refugee populations have settled since the increased refugee arrivals of 2015, interacting with a wide range of other previously settled ethnic groups (Fiddian-Qasmiyeh, 2016), including undocumented migrants (Varsanyi, 2008).

\section{The Context of Athens: Urban Development and Migrants' Settlement}

Despite the long theoretical tradition on the relationships between migrants' settlement dynamics and urban development, relevant research on southern European cities has emerged since the 1990s when the respective countries transformed from emigration to immigration countries. An approach that would directly apply analytical and theoretical insights from the US and northern European cities to those of Southern Europe would be ineffective (Arapoglou, 2006) due to several differentiating characteristics of the European South. The forms of urban development and trajectories of production processes, the reduced effect (or even absence) of central urban planning, the weak welfare state, the 'informal' processes characterising different aspects of everyday life (including labour), and the strong family networks functioning as a protective mesh in social reproduction processes constitute some of them (Leontidou, 1990; Vaiou et al., 2007; Vaiou \& Hadjimichalis, 2003). The morphology of urban space also differentiates the southern European cities, due to characteristics such as urban density, mixed land uses and social mixing.

During the last century, and especially in the first three post-war decades, the population of metropoli$\tan$ Athens increased significantly, from 1,500,000 in 1951 to 3,500,000 in 1981 (Maloutas \& Spyrellis, 2015). From the 1950s until the 1980s, several construction laws and housing production mechanisms (such as 'antiparochi,' a flats-for-land system) made it possible to house the increased population in the city. These procedures resulted in a densely-built environment in central Athens with problematic living conditions in the absence of urban and social infrastructures (Sarigiannis, 2000; Vaiou et al., 2007). As a consequence, from the late 1970 s onwards, a part of the middle- and upper-class Athenians left the central neighbourhoods and moved to the north-eastern and southern suburbs, resulting in urban sprawl and transformation of the socio-spatial map of the city. More specifically, from 1991 to 2001, the number of Greek residents in Athens Municipality reduced by 153,352, while from 2001 to 2011, it reduced by 137,813 (Maloutas, 2018, p. 142). As Maloutas and Spyrellis (2015) note:

Athens, a city where upper social classes traditionally lived in the centre and working classes lived in the periphery, came closer to the paradigm of the Englishspeaking world, where the affluent live in the suburbs and the working class live around the centre.
During the 1990s, migrant groups from Eastern European and Balkan countries settled in Greece. The migrant population of the Municipality of Athens increased from 25,873 in 1991 to 146,632 in 2001, reaching $18.40 \%$ of central Athens total population (Maloutas, 2018, p. 142). The majority of migrants settled in central urban neighbourhoods, in the old, available, and affordable housing stock that the partial movement of Greek residents had left behind, in absence of housing policies but in a context of increased employment opportunities. Since the late-2000s, migrant flows towards Greece from Middle Eastern, Asian and African countries, also settled in the same central Athenian neighbourhoods, in a context of economic crisis and deepening socioeconomic inequalities. According to the latest census data, the number of migrants in Athens Municipality increased to 150,586 in 2011, reaching $22.71 \%$ of Athens total population (Maloutas, 2018, p. 142), without including the large numbers of undocumented migrants. The vast majority of the migrant population comes from Albania (47.84\% of the foreign population in metropolitan Athens), while migrants from many other countries of origin follow in smaller numbers, such as Pakistan $15.83 \%$ of the foreign population in metropolitan Athens), Romania, Bulgaria, Georgia, etc. (Maloutas, 2018, p. 142). Since 2015, refugees from Syria, Afghanistan, Iraq, and other countries have also settled in Athens, temporarily or more permanently, either informally through networks of co-ethnics or through housing programs for asylum seekers (Papatzani, 2020).

In general, the geography of migrants' settlement is characterised both by dispersal in metropolitan Athens and by small ethnic concentrations in specific neighbourhoods (Balampanidis, 2019; Vaiou et al., 2007). In the residential multi-storey apartment buildings, migrants settled mainly in the affordable and smaller apartments on the lower floors and in the basement (Maloutas \& Karadimitriou, 2001). This settlement produced spatial proximity between migrants and locals and an unplanned interethnic cohabitation, resulting mostly in a vertical social differentiation rather than horizontal housing segregation (Maloutas \& Karadimitriou, 2001). Thus, a super-diverse urban environment was produced (Arapoglou et al., 2009) where the likelihood of 'contact' between migrants and locals remains high until today. In this context, questions on interethnic coexistence have already been explored by studies in the last two decades, focusing mainly on migrants that settled in Athens during the 1990s. These studies have unfolded migrants' sociospatial trajectories in the city and have traced trends of informal migrants' integration both in space and society (Balampanidis, 2019; Lazaridis \& Psimmenos, 2000; Vaiou et al., 2007; Vaiou \& Stratigaki, 2008).

Nevertheless, the socio-political context of the last decade has been polarised and socio-economic inequalities have increased. Migrant populations from Middle Eastern, Asian, and African countries have been constantly identified by the dominant media and political dis- 
course as 'strangers' and 'invaders,' as the scapegoats of the economic crisis. 'Illegals' (undocumented migrants) have especially been linked to criminality, fear, and the degradation of the centre of Athens. 'Ghetto,' a term used to characterise areas of central Athens, entered the media discourse in the late 2000s, while in the early 2010 s it also dominated the political discourse of official authorities (Kalantzopoulou, Koutrolikou, \& Polihroniadi, 2011). Both migrant groups and specific central Athenian neighbourhoods with relatively higher percentages of migrants have been stigmatised (Koutrolikou, 2015). These developments run in parallel with the rise of racism and exclusions both in terms of discourse and everyday violent practices against migrants at the local level (Kandylis \& Kavoulakos, 2011; Papatzani, in press). Even though the aforementioned perceptions and practices were reduced in 2015-2016, during the massive wave of solidary that emerged after refugees' arrivals, they were never abandoned. Thus, another side of everyday reality, characterised by social inequalities, racism, and exclusions existed during the last decade, and questions of interethnic coexistence remain open to investigation until today.

\section{Spaces of Everyday Encounters and Negotiations of Socio-Spatial Coexistence in Omonia}

The area of Omonia is located at the heart of the historic commercial centre of Athens (see Figure 1). Omonia square was one of the main squares planned by Kleanthis and Schaubert for Athens' first plan in 1833. The plan was later transformed and the form of Omonia square changed many times in the past decades. Until today the area attracts thousands of Athenian residents every day, due to the important transportation hub (metro, train, buses) located there. The area of our research, in the west of Omonia, is a mixed urban environment that historically constituted an area of small craft industries, wholesale and retail trade, private and public services and hotels. The western part of Omonia, compared to the east, always hosted less expensive services and commerce. Today, the area is characterised by high buildings, narrow streets, and arcades producing a densely built environment with a variety of public and semi-public spaces. There were always relatively few residences in Omonia compared to other neighbourhoods in central Athens due to its main commercial character. Furthermore, while in the past decades, local middleclass inhabitants moved from Omonia to the suburbs, some elderly inhabitants stayed and lower-class newcomers moved in (Arapoglou et al., 2009). Additionally, transformations in commerce and services (such as the removal of traditional sectors of activities) were followed by the establishment of new types of commercial and services activities.

Omonia has always been an important place for migrants, not only in terms of housing but also as regards commercial, labour and leisure activities (Noussia \& Lyons, 2009). It constituted the first arrival space for migrant populations for all migratory flows towards Greece. Research during the 1990s revealed that migrants settled in Omonia in old degraded hotels and the affordable rental market (Psimmenos, 2004). While some migrants who found other housing solutions moved towards other

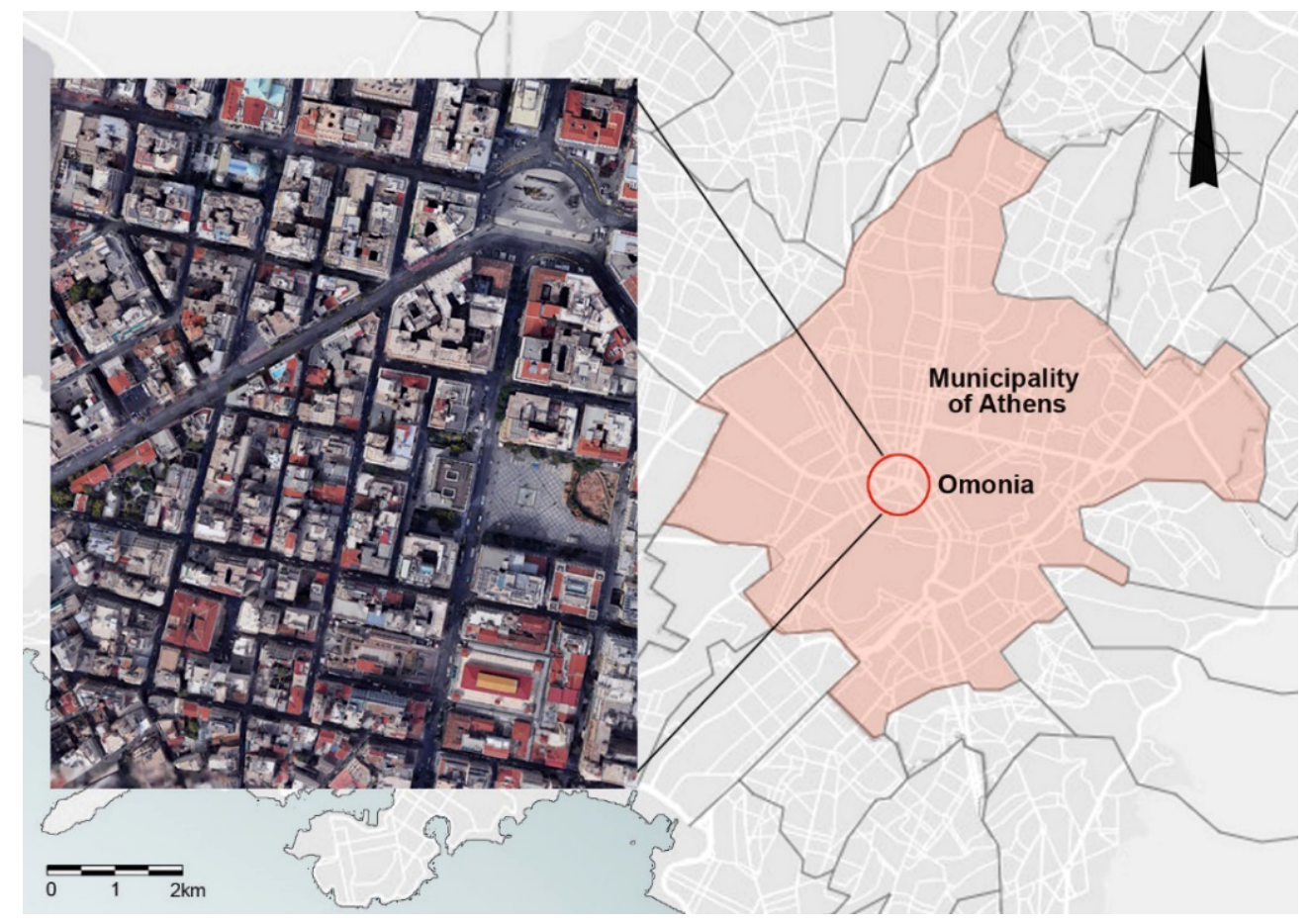

Figure 1. Map of the location of Omonia in the municipality of Athens. Based on EKKE-ELSTAT (2015) and Google Earth, with the authors' own editing. 
neighbourhoods in central Athens, for others, Omonia has been a place of residence until today. Additionally, Omonia attracted many of the first migrant businesses that were established in Athens since the late 1990s. Asian grocery shops, ethnic restaurants, transfer agencies, call centres and hair salons gradually took over the spaces where other sectors of commercial activity had prevailed in the past. Many businesses started by migrants are still functioning today, and their total number in Athens did not reduce during the economic crisis (Hatziprokopiou \& Frangopoulos, 2016). According to Hatziprokopiou and Frangopoulos (2016, p. 16), Omonia "epitomises the locus of migrant entrepreneurial ventures in Greece as a whole". To this day, the area functions as a place of residence, work and leisure for diverse ethnic groups, none of them dominant in the area (Arapoglou et al., 2009). Omonia was also one of the main areas of Athens stigmatised as a 'ghetto' in the dominant media and political discourse of the early 2010s, where police interventions against migrants took place from 2012-2014 (Papatzani, in press).

\subsection{Negotiations of Interethnic Cohabitation through Housing}

Migrants' housing patterns in Omonia take different forms. Despite the general character of Omonia as a place of commerce and services, densely-built and old multi-storey apartment buildings offer affordable housing options for migrants. Despite their general dispersal across metropolitan Athens, the percentage of migrants in Omonia is higher than average in Athens Municipality, as illustrated in Figure 2; yet it has to be mentioned, that this high proportion of foreigners is in an otherwise small total population of residents due to the generally low percentage of housing as land use in the area. Currently, Omonia also constitutes a place of concentration of apartments and hotels rented through the ESTIA accommodation program for asylum seekers (Papatzani, 2020).

The residential blocks-of-flats consist of large apartments on the upper floors with better views, ventilation and insulation, and lower floors with smaller, darker, devalued apartments that are usually rented

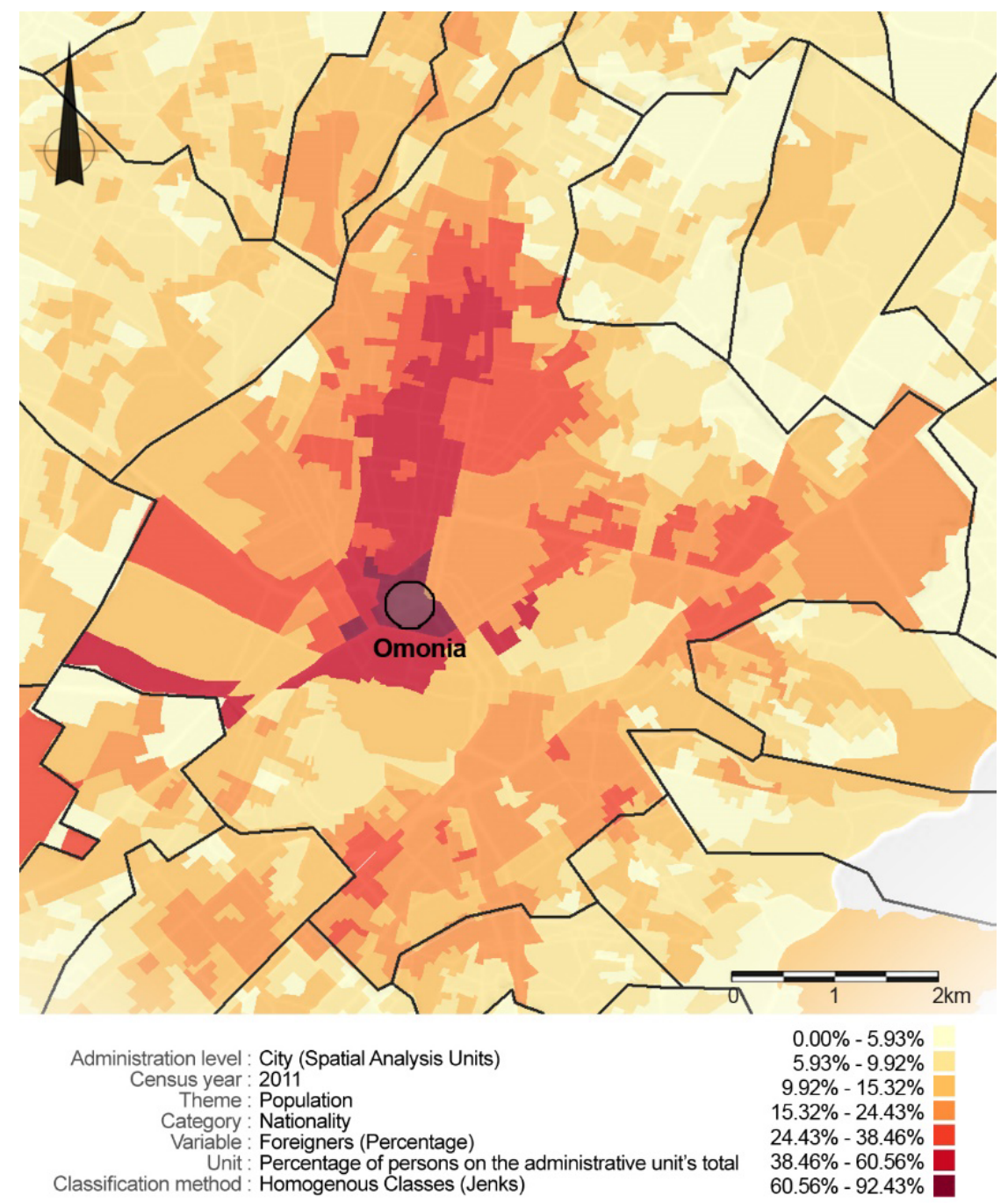

Figure 2. Percentages of foreign citizens on the administrative unit's total, in the Municipality of Athens. 2011 Census Data. Based on EKKE-ELSTAT (2015), with the authors' own editing. 
at affordable prices. Following the general migrants' residential patterns in Athens, a vertical ethnic differentiation emerges in the block-of-flats in Omonia (Maloutas \& Karadimitriou, 2001), in which the poorest population groups such as Pakistanis, Bangladeshis, and Africans, live in small apartments in the basement or on the ground floor, while the upper floors are inhabited by longer-settled migrants and Greek residents (see Figure 3). Co-ethnics usually cohabitate, and in case newcomers do not have legal documents, it is common to stay with documented migrants who are already settled in Athens.

In these block-of-flats where newcomers, migrants who have been living in the city for years and Greeks live in spatial proximity, interethnic relationships are established through everyday contacts and encounters with 'the Other.' These relationships are not only formed between migrants and Greeks, but also among different migrant groups. Relationships of mutual help and everyday familiarity created in mundane encounters in the buildings' shared spaces lead to a sense of belonging in the area:

I often help my neighbours to repair something broken. Apart from the Bangladeshi and Bulgarian neighbours, all the others are Greeks. Everyone loves me because they know me, you understand? They know me very well. (Abdul from Algeria, 8 November 2014)

In the block-of-flats, different inhabitants live on each floor. When people from diverse backgrounds and nationalities live in the same building, they get used to each other and get to know each other even though they might have cultural differences. (Eleni from Greece, 7 February 2019)

In Omonia, migrants do not live only in residential buildings. The majority of office and craft buildings in the area usually have shops on the ground floors, services and offices of both Greeks and migrants on intermediate floors, but also informal housing. Vacant spaces on the upper floors of these buildings are often rented by migrants. This type of housing is usually organised by informal networks providing accommodation per night or month to newcomers or migrants who lack other housing options. In some cases, this type of informal accommodation is also organised by smugglers, especially for migrants who plan to continue the journey. These practices include local-and at the same time transnationalunequal power relations between migrants and 'hosts' who usually exploit the formers' precarious situation. At the same time, they produce new spaces where interethnic relationships and networks are formed, of which some may last for years during migrants' future trajectories in the city, or even towards Europe:

Immigrants in Omonia rent the upper floors of former office buildings. Five or six people sleep on mattresses and stay there for months. They make the rental contract with the name of the one who has legal papers. (Jibran from Egypt, 16 November 2014)

Like in the past, Omonia currently functions as the very first arrival space for asylum seekers and refugees during their first day in Athens. The large number of hotels in Omonia usually host newcomers who are planning to

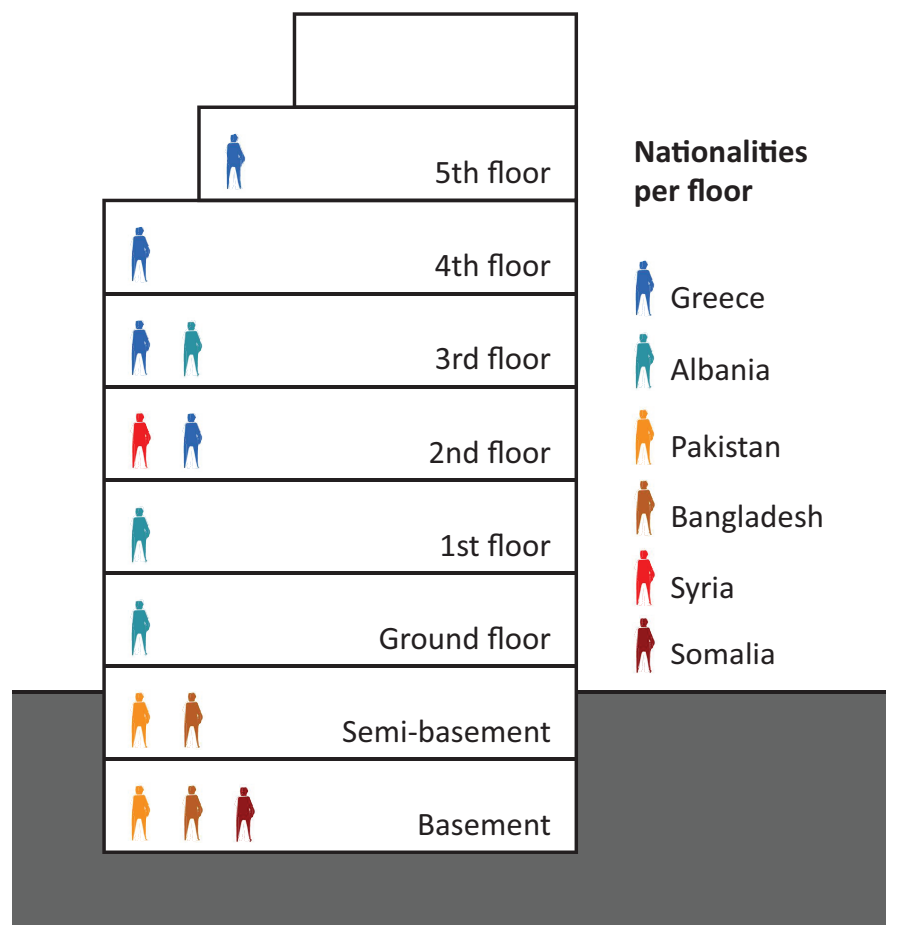

Figure 3. Nationalities of inhabitants per floor in the block-of-flats of Zarif (from Syria) in Omonia. Source: Authors. 
stay in the city temporarily and can afford it:

There is a very cheap hotel here. I think it is 25 euros a week. All the Syrians stay there, the ones who came out of the war. The hotel owner is well-known in Turkey and when people come from Syria, they receive his number for when they arrive in Athens. (Zarif from Syria, 11 November 2014)

I arrived here in Athens and a guy told me to go to Omonia because when someone arrives in Athens, he goes to Omonia. I came to Omonia at one o'clock in the night. I saw two guys from Africa. I spoke French and asked them where I could find a hotel because I was too tired. (Abdul from Algeria, 8 November 2014)

Newcomers often hear about Omonia before they arrive in Greece, usually during their stay in Turkey on their journey to Europe. They are informed that they should go to Omonia because of the presence of co-ethnics as well as different kinds of goods and services, such as cheap hotels, money transfer, travel agencies, ethnic shops and various immigrant organisations. Thus, for newcomers, the character of Omonia as a first arrival space redefines the area as a transnational pole of attraction and as a gateway for migrants' transnational movements.

\subsection{Ethnic Entrepreneurship as a Catalyst for Interethnic Coexistence}

In addition to affordable housing, the building stock of old office and craft buildings in Omonia offers a variety of flexible small-scale spaces for diverse activities and shops, both on the ground floor and on the upper floors. Due to the building structure of the block-of-flats, consisting of a concrete structure with columns and non-loadbearing walls, it is relatively easy to adapt spaces, making them larger or smaller according to specific needs. Many of the shops in Omonia are owned by migrants who have been residing in the Greek capital for years. The majority are migrants from China, Pakistan, Albania, Bangladesh, and Syria (see Figure 4). They invest in different types of commercial and services activities. Commerce includes clothing, electronics shops and mini markets attracting both migrants and lower-income Greeks as clients, while services such as ethnic restaurants, travel agencies, or internet cafes target primarily migrants' needs. In these shops, a wide range of interethnic relationships is negotiated on an everyday level, ranging from relationships between migrant shop owners, employees and Greek clients to relationships between different ethnic groups.

In some cases, particular activities-both in terms of their type and the owners' nationality-are specifically located in Omonia. For example, the concentration of travel agencies, transferring people and goods from and to Balkan countries, has been located in the northern part of Omonia since the 1990s, maintaining its historical spatial continuity (Psimmenos, 2004). Nevertheless, the relationships between nationalities, economic activities and locations are not static but transform dynamically over the years. Additionally, in some cases, businesses of specific ethnic groups come together in certain streets, creating micro-concentrations in terms of the owners' nationality. It has been observed, for example, that Pakistani shops are located in different streets than those of Bangladeshis or Arabs, as also ob-

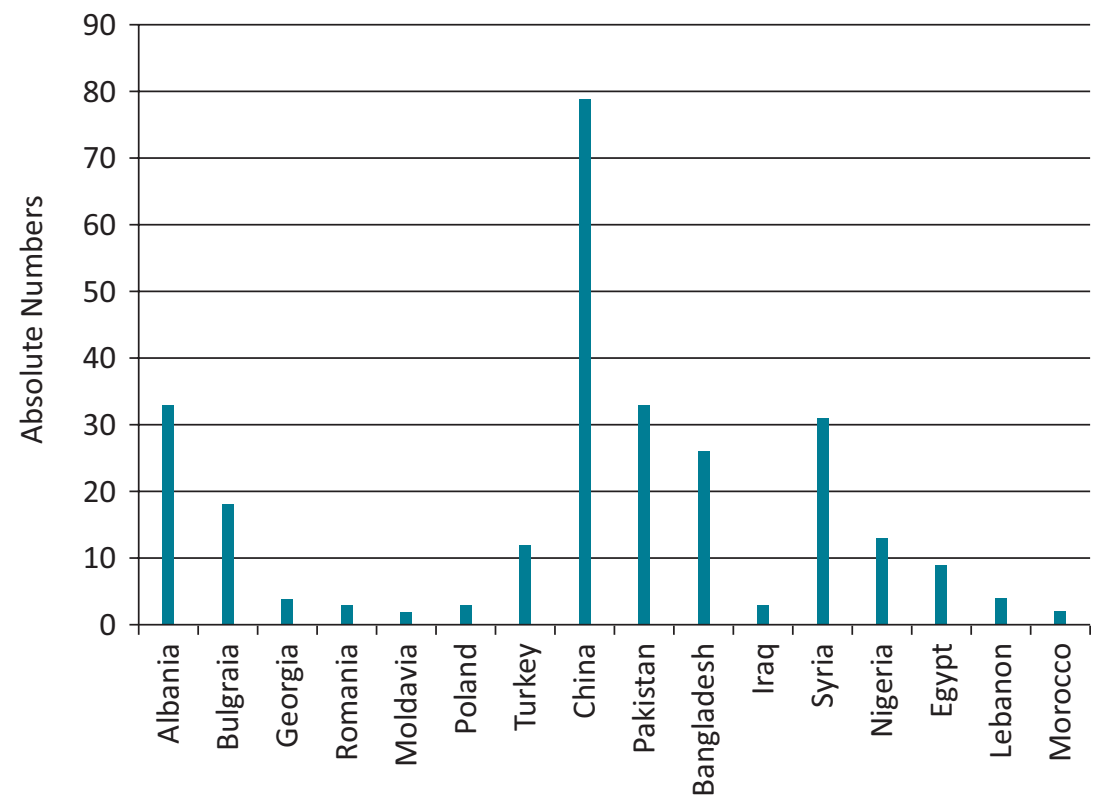

Countries of Origin

Figure 4. Countries of origin of the migrant shop owners in Omonia, 2014 data, in absolute numbers. Based on data from the Athens Chamber of Commerce and Industry, with the authors' own editing. 
served by Noussia and Lyons in their study on Omonia a decade ago (Noussia \& Lyons, 2009). These microconcentrations help migrants to maintain and strengthen social and commercial relationships and ethnic networks. However, they do not constitute strictly bounded spatial systems. Instead, both community networks of coethnics are strengthened around them, and interethnic relationships between different ethnic groups and Greeks are constantly reproduced. It has also been observed that when owners change, the new owner sometimes keep the ethnic decoration and character of the shop, even if the former owner was from a different country of origin:

Different nationalities gather in different streets. The shops and public space in Sofokleous and Anaksagora Street are mainly appropriated by Pakistanis, Menadrou street is for Afghans, Geraniou street is occupied by Bangladeshis, and the commercial and public spaces in Sokratous street are mainly used by Arabs. (Hazar from Pakistan, 4 February 2019)

While the majority of the streets accommodate diverse shops and businesses, other types of spaces such as the various arcades in the area, or the upper floors of buildings are appropriated for more informal economic activities. Shops without official operating licenses, spaces functioning as meeting places for irregular activities, and informal mosques can be found in a wide range of different semi-public or private spaces. The third floor of a former office building in Sofokleous street has been transformed into a 'shopping mall' where products are sold informally. In an Indian restaurant in the area, people hang out with friends and watch an Indian cricket match, while in the back of the restaurant, deals are made about valuable information on legal status procedures. In these in-between spaces, migrants hide away from the visibility of the street level, gaining a sense of security and anonymity for covering a wide range of survival and social needs. Engaging with informal economic practices presupposes both the existence of relationships and networks of trust and also migrants' embeddedness in the wider socio-economic and politico-institutional environment, including "sets of rules and regulations, neighbourhoods, associations and business traditions" (Kloosterman, van der Leun, \& Rath, 1999, p. 262).

\subsection{Micropublics of Everyday Encounters}

The centrality of Omonia attracts both migrants permanently living in Athens and newcomers. For the first, Omonia constitutes a pole of attraction for leisure activities, such as worship practices in the informal mosques, or meeting friends and hearing about news from the home country. The latter usually gather in the area to gain information about their legal status procedure or employment and housing opportunities, to meet their networks, create new ones, or find possible ways to leave the country. Omonia is a place of attraction even for people living and working in other neighbourhoods of Athens or remote areas of Attica (see Figure 5), and a significant number of them visit the area many days per week. Especially on Sundays, when the shops in Omonia are open (contrary to the rest in Athens), hundreds of migrants get together in the area, transforming it into a mass meeting place. Said Haifa from Syria (24 January 2018): "One could call Omonia the 'square of refugees or square of Arabs.' We all gather here since everyone lives in different parts of the city."

Omonia is also an important place for locals due to the transportation hub and the variety of cheap markets and services provided. The super-diversity of the place, as well as migrants' cultural presence (e.g., through the labels and posters in their native languages covering walls or the facades of stores), familiarise the Greeks with the presence of migrants in the city (Vaiou et al., 2007). Through locals' and migrants' interactions in Omonia, otherness is encountered in urban space and socio-spatial coexistence is negotiated on a daily basis.

The large, open public spaces in the area are often appropriated by migrants. In the square of St Constantine Church, women from the Balkans and Eastern Europe gather in large numbers each Sunday, on their day-off from their jobs as domestic workers in middle and upper-class Athenians' houses. They meet each other, exchange news, and send money or goods to their home countries through the travel agencies located close by. In Omonia square, asylum seekers and refugees meet friends on their way shopping, or for advice on the asylum procedure.

Apart from gatherings in public spaces, a variety of semi-public spaces emerge as hangouts and benchmarks for a wide range of ethnic groups. Migrant shops function as vital meeting and leisure places. Gatherings of Pakistani or Bangladeshi men are formed and maintained outside co-ethnic shops. The inside of specific shops constitutes a meeting place for gathering information on $\mathrm{mi}-$ gration journeys towards Europe, especially for newly arrived migrants that remain undocumented. Both the shops' interior and the public space outside them function as places of encounters. In the arcades people meet with friends, exchange news, try to find a job, or to exchange fake documents for their everyday navigation in the city in case of police control. An old man from Pakistan has had his own corner for the last ten years, on the pavement at a crossroads, selling mobile phone cards for cheap communication with his country of origin, attracting many co-ethnics every day. Outside the informal mosques, in the arcades or on the streets, people gather not only to pray but also to socialise. Gatherings of migrants in these diverse spaces create new types of micropublics of everyday contacts and encounters (Amin, 2002) that are crucial to migrants' everyday lives and socio-spatial settlement in Athens. These micropublics emerge in private and public but mainly in semipublic, in-between spaces, redefining the boundaries 


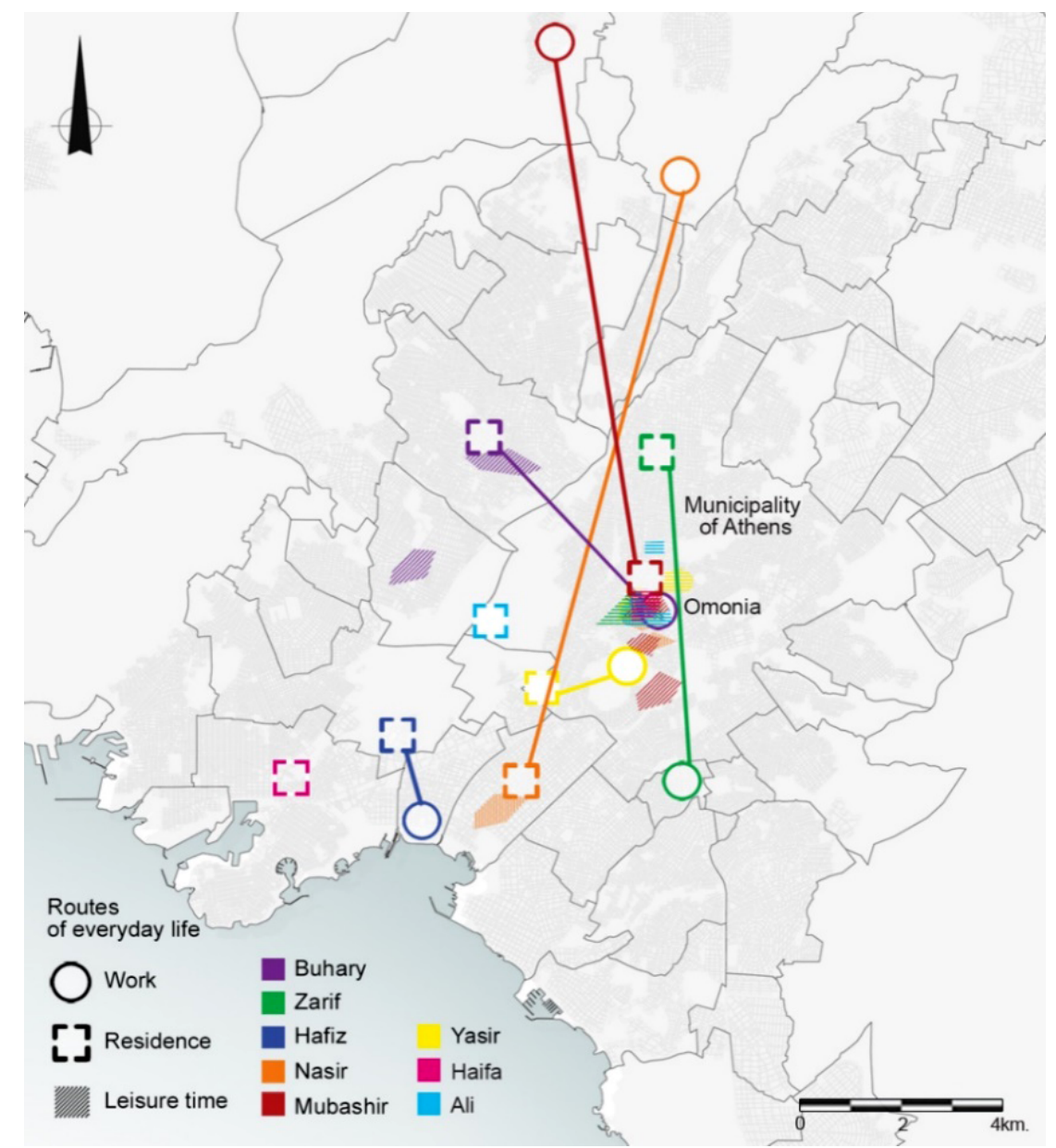

Figure 5. Map of the places and routes of everyday life in the city: Work, residence and leisure time of eight of the migrant interviewees. Source: Authors.

between the public and the private spatial and social sphere. Nevertheless, since the boundaries between different spheres are fluid (Wessendorf, 2014), migrants constantly reproduce different spaces of encounters as micropublics that function according to their needs. The presence of the police in the area, which has strengthened over the last decade, sometimes disrupts the encountering processes, but after its removal, encounters and micropublics are recreated, maintaining a dynamic continuity over time and space (Papatzani, in press):

Migrants come here to find each other and to get information. To tell you an example, after 10 years of living in Athens, I bumped into a friend from my childhood I didn't even know lives in Greece. Then the world seemed so small, the world is in Omonia. (Hazar from Pakistan, 4 February 2019)

Micropublics are not bounded by strict or fixed social boundaries, even though they are usually formed by the appropriation of space by people of the same nationality, gender, age, duration of settlement in Athens, or legal status (Noussia \& Lyons, 2009). For example, newcomers and already-settled migrants usually create dif- ferent micropublics due to their differentiated needs, practices, and activities. Nevertheless, as also Noussia and Lyons argue, "access to distinct spaces is negotiated over time within migrant groups" (Noussia \& Lyons, 2009, p. 601). The constant movement and flows in Omonia and the overlapping practices and needs disrupt the socio-spatial boundaries of the micropublics in a mundane way. Boundaries between migrants and locals are negotiated through diverse activities such as shopping in the same shops or inhabiting in the same buildings. Legal status boundaries are disrupted in micropublics where the needs of the undocumented migrants meet the experiences and know-how (Vaiou et al., 2007) that the documented have gained. Gendered boundaries are blurred in the places where both men's and women's needs are covered, in the case of gatherings for sending money and products to their home countries, outside the travel agencies, for example. In the informal mosques, ethnic boundaries are also disrupted as people from different nationalities meet in the same place. Boundaries between newcomers and already-settled migrants are also negotiated in the micropublics formed inside and outside the co-ethnic shops where their practices and needs overlap. These micropublics unfold in a wide range of 
spaces: from specific places where members of one ethnic group can find each other, to spaces where the needs of different ethnic groups overlap, to spaces where everyone is on equal footing. The social characteristics, according to which micropublics are initially formed, are constantly redefined and none of them manages to prevail permanently. Overlapping shared spaces and micropublics of everyday encounters are constantly being reproduced through dynamic social processes and practices based on everyday needs.

\section{Conclusion}

Drawing on the scholarship on everyday encounters with difference in super-diverse contexts and aiming to go beyond the 'ethnic lens' (Glick Schiller \& Çağlar, 2009), this article has offered some insights on Omonia, a superdiverse urban context where newcomers coexist with already-settled migrants and locals (Fiddian-Qasmiyeh, 2016; Varsanyi, 2008). The dynamic context of Omonia is reproduced by the simultaneous existence of a wide range of different housing, entrepreneurship, and leisure activities that unfold its multilevel importance for migrants' everyday lives in the city: as a place of long-term residence, a pole of attraction for diverse ethnic groups and locals, and as an arrival space for newcomers.

Super-diversity and close spatial proximity characterising the settlement of migrants and locals in Athens form a fertile ground for opportunities of interethnic coexistence. Nevertheless, the processes of encountering difference that are produced through this ground could neither be presumed as merely positive nor conceived as static, especially in the context of deepening inequalities, strict migration laws, institutionalised exclusions, racism and the absence of integration policies. In this article, we claim that beyond the significant importance of the diverse and spatially mixed urban environment of Athens, further conditions should prevail for the production of interethnic coexistence. In other words, there is a 'distance' to be covered between spatial proximity and social proximity. In this direction, it is the everyday encounters and micropublics that play a crucial role. More importantly, it is the micropublics that are created through practices and activities emerging from everyday survival and social needs that could dynamically cover the aforementioned 'distance,' even if they remain, until today, less researched by the relevant scholarship.

These micropublics, as 'place-specific' and 'needsspecific' everyday encounters created by migrants themselves, are constantly open to negotiation. They emerge mainly in semi-public, in-between spaces and they redefine the boundaries between different spatial and social spheres. As our case study in Omonia revealed, micropublics are dynamically open to transformation, able to redefine pre-existing social identities and boundaries, to disrupt local power relations of inequality and control, and to foster interethnic coexistence. As such, everyday encounters incorporate processes of not only ne- gotiating difference and socio-spatial coexistence, but also belonging in the city. They enact a politics of belonging (Leitner, 2012), permitting migrants to make their place and claim their right to the city (Lefebvre, 1968/2007) through mundane and usually implicit-yet vital-everyday practices of contestation.

\section{Acknowledgments}

We would like to thank the editors and the anonymous reviewers for their constructive comments on earlier versions of this article. We would also like to thank the Creative Industries Fund NL for giving us the opportunity for collaboration between Athens and Rotterdam, and Dina Vaiou for her guidance on a part of the implemented research.

\section{Conflict of Interests}

The authors declare no conflict of interests.

\section{References}

Ahmed, S. (2000). Strange encounters: Embodied Others in postcoloniality. London and New York, NY: Routledge.

Allport, G. (1954). The nature of prejudice. Boston, MA: Addison-Wesley.

Althusser, L. (2006). Philosophy of the encounter. Later writings, 1978-87. London and New York, NY: Verso.

Amin, A. (2002). Ethnicity and the multicultural city: Living with diversity. Environment and Planning A: Economy and Space, 34(6), 959-980.

Aptekar, S. (2019). Super-diversity as a methodological lens: Re-centring power and inequality. Ethnic and Racial Studies, 42(1), 53-70.

Arapoglou, V. (2006). Immigration, segregation and urban development in Athens: The relevance of the LA debate for southern European metropolises. The Greek Review of Social Research, 121, 11-38.

Arapoglou, V., Kandylis, G., Kavoulakos, K. I., \& Maloutas, T. (2009). The new social geography of Athens: Migration, diversity and conflict. Synchrona Themata, 107, 57-66.

Balampanidis, D. (2019). Housing pathways of immigrants in the city of Athens: From homelessness to homeownership. Considering contextual factors and human agency. Housing, Theory and Society, 37(2), https://doi.org/10.1080/14036096.2019.1600016

Berg, M. L., \& Sigona, N. (2013). Ethnography, diversity and urban space. Identities: Global Studies in Culture and Power, 20(4), 347-360.

EKKE-ELSTAT. (2015). Panorama of Greek census data 1991-2011 [Internet Application]. Athens: National Centre for Social Research and Hellenic Statistical Authority. Retrieved from https://panorama.statistics. gr/en

Fiddian-Qasmiyeh, E. (2016). Refugee-refugee relations 
in contexts of overlapping displacement. Spotlight on the urban refugee 'crisis': Reflections on cities, citizenship, and the displaced. International Journal of Urban and Regional Research. Retrieved from https://www.ijurr.org/spotlight-on/the-urbanrefugee-crisis-reflections-on-cities-citizenshipand-the-displaced/refugee-refugee-relations-incontexts-of-overlapping-displacement

Fraser, N. (1992). Rethinking the public sphere: A contribution to the critique of actually existing democracy. In C. Calhoun (Ed.), Habermas and the public sphere (pp. 109-142). Cambridge, MA: MIT Press.

Glick Schiller, N., \& Çağlar, A. (2009). Towards a comparative theory of locality in migration studies: Migrant incorporation and city scale. Journal of Ethnic and Migration Studies, 35(2), 177-202.

Goffman, E. (1961). Encounters. Two studies in the sociology of interaction. Indianapolis, IN: Bobbs-Merrill.

Hall, S. M. (2015). Super-diverse street: A 'transethnography' across migrant localities. Ethnic and Racial Studies, 38(1), 22-37.

Hatziprokopiou, P., \& Frangopoulos, Y. (2016). Migrant economies and everyday spaces in Athens at times of crisis. City, 20(1), 61-74.

Horgan, M. (2012). Strangers and strangership. Journal of Intercultural Studies, 33(6), 607-622.

Isin, E. F. (2007). City-state: Critique of scalar thought. Citizenship Studies, 11(2), 211-228.

Kalantzopoulou, M., Koutrolikou, P., \& Polihroniadi, K. (2011). The dominant discourse for the center of Athens. Encounter Athens. Retrieved from https:// encounterathens.files.wordpress.com/2011/05/ encounter-logos-15052011.pdf

Kandylis, G., \& Kavoulakos, K. I. (2011). Framing urban inequalities: Racist mobilisation against immigrants in Athens. Greek Review of Social Research, 136, 157-176.

Kloosterman, R., van der Leun, J., \& Rath, J. (1999). Mixed embeddedness: (In)formal economic activities and immigrant businesses in the Netherlands. International Journal of Urban and Regional Research, 23(2), 253-267.

Koutrolikou, P. (2015). Socio-spatial stigmatisation and its 'incorporation' in the centre of Athens, Greece. City, 19(4), 510-521.

Lazaridis, G., \& Psimmenos, I. (2000). Migrant flows from Albania to Greece: Economic, social and spatial exclusion. In R. King, G. Lazaridis, \& C. Tsardanidis (Eds.), Eldorado or fortress? Migration in Southern Europe (pp. 170-185). London: Macmillan.

Lefebvre, H. (1974). La production de l'espace [The production of space]. Paris: Anthropos.

Lefebvre, H. (2007). The right to the city. Space and politics. Athens: Koukida. (Original work published 1968)

Leitner, H. (2012). Spaces of encounters: Immigration, race, class, and the politics of belonging in smalltown America. Annals of the Association of American Geographers, 102(4), 828-846.
Leontidou, L. (1990). The Mediterranean city in transition: Social change and urban development. Cambridge: Cambridge University Press.

Maloutas, T. (2018). The social geography of Athens. Social groups and the built environment in a South European metropolis. Athens: Alexandria.

Maloutas, T., \& Karadimitriou, N. (2001). Vertical social differentiation in Athens. Alternative or complement to urban segregation? International Journal of Urban and Regional Research, 25(4), 699-716.

Maloutas, T., \& Spyrellis, S. N. (2015). Vertical social segregation in Athenian apartment buildings. Athens Social Atlas. Retrieved from https://www. athenssocialatlas.gr/en/article/vertical-segregation

Massey, D. (2005). For space. London: Sage.

Matejskova, T., \& Leitner, H. (2011). Urban encounters with difference: The contact hypothesis and immigrant integration projects in eastern Berlin. Social \& Cultural Geography, 12(7), 717-741.

Mayblin, L., Valentine, G., \& Andersson, J. (2016). In the contact zone: Engineering meaningful encounters across difference through an interfaith project. The Geographical Journal, 182(2), 213-222.

Nast, J., \& Blokland, T. (2014). Social mix revisited: Neighbourhood institutions as setting for boundary work and social capital. Sociology, 48(3), 482-499.

Noussia, A., \& Lyons, M. (2009). Inhabiting spaces of liminality: Migrants in Omonia, Athens. Journal of Ethnic and Migration Studies, 35(4), 601-624.

Papatzani, E. (2020). The geography of the 'ESTIA' accommodation program for asylum seekers in Athens. Athens Social Atlas. Retrieved from https://www.athenssocialatlas.gr/en/article/thegeography-of-the-estia-accommodation-program

Papatzani, E. (in press). Encountering everyday racist practices: Socio-spatial negotiations of immigrants' settlement in Athens, Greece. International Journal of Urban and Regional Research.

Park, R. E., Burgess, E. W., \& McKenzie, R. D. (Eds.). (1925). The city. London and Chicago, IL: University of Chicago Press.

Psimmenos, I. (2004). Immigrants and social exclusion in the contemporary city: The case of Athens. Geographies, 7, 65-82.

Sarigiannis, G. (2000). Athens 1830-2000. Evolution, urban planning, transportation. Athens: Simmetria.

Wolff, K. (Ed.). (1950). The sociology of Georg Simmel. Glencoe, IL: Free Press.

Soja, E. (1989). Postmodern geographies. The reassertion of space in critical social theory. London and New York, NY: Verso.

Soja, E. (2000). Postmetropolis: Critical studies of cities and regions. Oxford: Blackwell.

Tasan-Kok, T., van Kempen, R., Raco, M., \& Bolt, G. (2013). Towards hyper-diversified European cities: A critical literature review. Utrecht: Utrecht University, Faculty of Geosciences.

Vaiou, D., Bacharopoulou, A., Fotiou, T., Hatzivasileiou, 
S., Kalandides, A., Karali, M., . . . Tounta, F. (2007). Intersecting patterns of everyday life and sociospatial transformations in the city: Migrant and local women in the neighbourhoods of Athens. Athens: L-Press/NTUA.

Vaiou, D., \& Hadjimichalis, C. (2003). With the sewing machine in the kitchen and the Poles in the Fields: Cities, regions and informal work. Athens: Exadas.

Vaiou, D., \& Stratigaki, M. (2008). From 'settlement' to 'integration.' Informal practices and social services for women migrants in Athens. European Urban and Regional Studies, 15(2), 119-131.

Valentine, G. (2008). Living with difference: Reflections on geographies of encounter. Progress in Human Geography, 32(3), 323-337.

van Kempen, R., \& Wissink, B. (2014). Between places and flows: Towards a new agenda for neighbourhood research in an age of mobility. Geografiska Annaler:
Series B, Human Geography, 96(2), 95-108.

Varsanyi, M. W. (2008). Immigration policing through the backdoor: City ordinances, the "right to the city" and the exclusion of undocumented day laborers. Urban Geography, 29(1), 29-52.

Vertovec, S. (2007). Super-diversity and its implications. Ethnic and Racial Studies, 30(6), 1024-1054.

Wessendorf, S. (2010). Commonplace diversity: Social interactions in a super-diverse context (MMG Working Paper 10-11). Göttingen: Max Planck Institute for the Study of Religious and Ethnic Diversity.

Wessendorf, S. (2014). 'Being open, but sometimes closed.' Conviviality in a super-diverse London neighbourhood. European Journal of Cultural Studies, 17(4), 392-405.

Young, I. M. (1990). Justice and the politics of difference. Princeton, NJ: Princeton University Press.

\section{About the Authors}

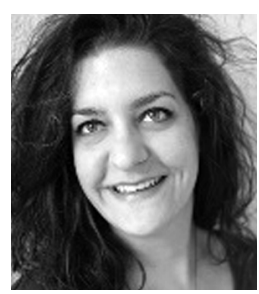

Eva (Evangelia) Papatzani is a PhD Candidate in Urban Social Geography at the Department of Urban and Regional Planning, School of Architecture, National Technical University of Athens, Greece. She holds an MSc in Urban and Regional Planning (N.T.U.A.) and a diploma in Architecture from the Aristotle University of Thessaloniki. She has participated as a researcher in several European and national research projects, conducted by different universities in Greece. Her research focuses on migration, diversity in urban space, housing, socio-spatial segregation, interethnic relationships, encounters, and urban policies.

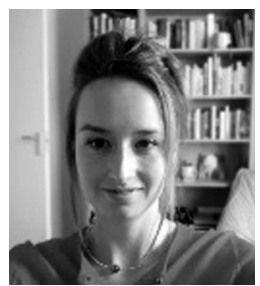

Lena Knappers graduated in 2017 from the Urbanism Department at TU Delft. She works as an urban designer and advisor to the Chief Government Architect in The Hague (NL). Knappers received a grant from the Creative Industries Fund NL to work on her design project in which she investigates how to organise migration in European urban space. 